\title{
THE RELATIONSHIP BETWEEN THE CORPORATE SOCIAL RESPONSIBILITY AND THE COST OF THE CAPITAL OF THE COMPANIES LISTED ON THE NIGERIAN STOCK EXCHANGE
}

\author{
Nyore Sandra Ofogbe*, Chidiebere Nnamani, Chika Anastesia Anisiuba and Charity \\ Nkeiru Ezuwore-Obodoekwe \\ University of Nigeria, Faculty of Business Administration, Accountancy Department, Nsukka, Nigeria
}

\begin{abstract}
This study is aimed at analyzing the influence of Corporate Social Responsibility (CSR) on the Cost of the Capital $(\mathrm{CoC})$ of the companies quoted on the Nigerian Stock Exchange (NSE). The annual panel data of the 32 companies quoted on the NSE pertaining to the period from 2005 to 2019, were judgmentally selected. The Thomson Reuthers Index was used as the measure for CSR, whereas the Cost of Equity $(\mathrm{CoE})$ and the Cost of Debt $(\mathrm{CoD})$ were used as the measure for $\mathrm{CoC}$. The findings revealed the existence of a positive/negative nonsignificant relationship, on the one hand, and a positive/negative significant relationship as well, on the other, between CSR and CoC. The results obtained are supportive of the findings found in scholars' works, especially those in the developed countries in which this aspect has extensively been explored. To conclude, the companies that spend on CSR have a better chance of accessing capital at a better and low cost. Based absolutely on the findings, the researcher advocates that investment should incessantly be made in the issues concerning CSR, given the fact that, if consistently made, such investment may ease access to funds at a reduced cost.
\end{abstract}

Keywords: corporate social responsibility, cost of capital, Thomson Reuters Index, cost of equity, cost of debt

JEL Classification: M1, M4

\section{INTRODUCTION}

Corporate Social Responsibility (CSR) has globally turned out to be exceptionally essential. The same has been supported by an increasing number of the

* Correspondence to: N. S. Ofogbe, University of Nigeria, Faculty of Business Administration, Accountancy

Department, Nsukka, Nigeria, e-mail: Sandy4pg@gmail.com academic papers that highlight practical reasons for firms to integrate CSR in their practices (Joëla, 2017; Youngkyung \& Jungmu, 2019; Chin-Chen, Fengyi, Teng-Shih, \& Chia-Ming, 2020). In their paper, S. M. Barbara and F. I. Maria (2017) stipulated the fact that a growing range of companies had been paying attention to corporate responsibility issues. CSR depicts companies' capacity to be socially responsible 
for social growth and development. It demonstrates the activities that communicate business obligations to all constituent stakeholders (Votaw, 1973). The interesting question is, why, of their own accord, do some firms spend their scarce resources on social goals while others do not?

There are several factors that motivate companies to report on CSR. As reported by Ernst \& Young (2013), companies see improved reputation as the most valuable contribution made to them by CSR. A. Ansong, S. K. Agyei and E. Marfo-Yiadom (2017); M. Moskowitz, 1972; and O. Hawn, A. Chatterji and W. Mitchell (2011), accordingly opined the factors including gaining social legitimacy and goodwill, attracting and maintaining high-quality employees, and allowing for the healthier marketing of products and services. A. Goss and G. S. Roberts (2011); K. M. Menz (2010) and B. Cheng, I. Ioannou and G. Serafeim (2014), however, advocate that investing in corporate social initiatives increase access to external financing, such as bank loans, a debt and equity issues.

To some extent, CSR is connected with CoC alongside the investor's decision on funds allocation. As opined by P. M. Healy and K. G. Palepu (2001), more disclosure findings might provide additional facts and consequently decrease the information irregularity dilemma, knowing fully well that without an adequate piece of information, investors will find it tough to differentiate between good and bad investments. Introducing CSR disclosure would align the interest of the parties' concern and create incentives for CSR disclosure.

The Cost of Capital (CoC) is the cost of the company's funds, both the debt and the equity. $\mathrm{CoC}$ is the company financing costs when borrowing money, using equity financing or selling bonds in order to fund projects or investments. In particular, companies' cost of capital can reflect CSR risks and benefits (Weber, 2008). For example, firms might benefit from lower interest rates (Goss \& Roberts, 2011) and higher access to debt capital through CSR (Cheng, Ioannou \& Serafeim, 2014).

There is a well-established fact that investors in the public debt are more sensitive to and more concerned about agency costs and the asymmetric information problem than private debt investors, such as banks (Leland \& Pyle, 1977; Krishnaswami, Spindt \& Subramaniam, 1999; Denis \& Mihov, 2003). The presence of these two frictions could thus essentially limit a firm's access to the public debt market. Consequently, firms may have to rely on relatively more costly bank debt financing.

This study primarily investigates the effect of CSR performance on $\mathrm{CoC}$ by obtaining evidence from a cross-section of the companies quoted on the Nigerian Stock Exchange.

Bearing in mind the goal of the study, the study itself ascertains whether performing CSR has in any way led to easy access to capital at a reduced cost among the companies quoted on the NSE. The study is empirically oriented and employs quantitative methods, such as the descriptive method, correlation, the unit root test, the random effect model and diagnostic tests.

Beside the introduction, the rest of the paper is structured as follows: in the next section, the problem statement is presented and testable hypotheses are developed; this is followed by a related literature review pertaining to the subject matter of the study and the method applied in the study as well. Finally, the analysis, discussion, the conclusions, and the recommendations are presented.

\section{Problem statement}

In the past years, CSR has turned out to be the most crucial subject issue in doing business. The argument over the intrinsic value of CSR revolves around if such investments are value-enhancing or if they are the value-destroying manifestation of agency conflicts (Allen \& Gordon, 2011). The quest for social responsibility helps organizations to create values, be accountable to stakeholders at large and gain performance.

Accordingly, society tends to be in an advantaged position in relation to the firms that act in a socially responsible manner in comparison with their 
counterparts. It is therefore imperative for firms to channel their societal performance, which may usually be done through the disclosure of the CSR information which will ultimately be beneficial to all (Dhaliwal, Li, Tsang \& Yang, 2011). The information disclosed must be useful, timely, and not too costly to collect (Dubbink, Graafland \& Van Liedekerke, 2008). Regrettably, CSR implementation is more complicated to perform than to explain. The reason for that lies in the fact that a company's interests and culture differ (that is, humanistic vs profit maximization), and a probable difference in interest between managers and shareholders varies, too (Banerjee, 2008).

Humanistic corporations generally tend to behave in a socially responsible manner (Smith, 2003; Lee, 2008; Walker \& Wan, 2012), while profit-maximizing firms seek their interest not minding whether it is at the expense of anyone else or not (Dugger, 1989; Basu \& Palazzo, 2008; Menz, 2010).

Despite the growing body of the extant studies on CSR among companies in Nigeria, a good number of the studies were dedicated to the relationship between CSR and the Financial Performance (FP) of the corporations listed on the NSE (Agbiogwu, Ihendinihu \& Okafor, 2016; Wekesa, 2017; Abdulaziz, 2018; Odunayo \& Ibidolapo, 2018; Stephen \& Rebecca, 2018; Ehioghiren \& Eneh, 2019). This study refers to a well-known debate from an innovative point of view: CSR and CoC. The relationship between CSR and $\mathrm{CoC}$ has not yet been investigated a lot in Nigeria. In addition to that, the largest number of the studies on the concept of CSR that have sprouted in Nigeria's companies are focused on CSR and its effect on FP. These studies test the correlation between CSR and FP, simultaneously neglecting the point of view concerning CSR and CoC.

Besides, the biggest number of the studies used the amount disclosed in a financial statement, in questionnaires and a few in the KLD index as the measure for CSR (Ajide \& Aderemi, 2014; Joseph \& Michah, 2016, Odunayo \& Ibidolapo, 2018). This study investigates the relationship between CSR and the $\mathrm{CoC}$ of the companies listed on the NSE using the Thomson Reuther Index. It specifically examines the correlation between CSR and CoE, CoD. There is a dearth of papers in the literature on this aspect. This is the reason why the focal point here is to explore the effect CSR has on the cost of capital (CoC) and the costs of debt $(\mathrm{CoD})$ amongst Nigerian companies. This is necessary because the result of the research, if positive, may motivate other companies not in compliance with CSR to adopt CSR as a part of their business operations.

In light of the above-mentioned, the study:

- examines whether CSR performance by the companies listed on the NSE included in the sample has in any way led to easy access to the cost of equity at a reduced cost, and

- ascertains whether CSR performance by the companies listed on the NSE and included in this sample has led to easy access to the cost of debt at a reduced cost.

Bearing in mind the foregoing, the following is hypothesized.

H1: Corporate social responsibility correlates with the cost of equity of the companies quoted on the Nigerian Stock Exchange.

$\mathrm{H} 2$ : Corporate social responsibility correlates with the cost of debt of the companies quoted on the Nigerian Stock Exchange.

\section{LITERATURE REVIEW}

\section{Corporate social responsibility and the cost of equity}

The empirical findings revealed the fact that the companies that had disclosed CSR had better and quicker access to new capital, and also faced fewer costs. Companies showed their probable shareholders that they were competitive and lowered the menace of investment by reporting on CSR (Cheng, Ioannou \& Serafeim, 2014). They argued that the extent to which CSR is present could lessen CoE capital 
for companies. This is also owing to their better commitment to and their engagement with the stakeholders based on mutual trust and cooperation (Jones, 1995). CSR adoption makes stakeholders feel stronger self-assurance and trust in companies. It makes them see the companies as the subject sharing the same common belief with them, and agency costs are reduced. In another study, W. Dhaliwal et al (2011) revealed that investors were most likely to invest in a more transparent company. With reliance on increased trust in suchlike companies, investors were more prone to lessen $\mathrm{CoE}$ capital.

\section{Corporate social responsibility and cost of debt}

More to the point, increased CSR decreases CoD. Studies conducted in the past also revealed the fact that, in the long run, performing CSR could result in a reduction in CoD. An example is a survey carried out by A. Goss and G. S. Robert (2011). Their study suggests that CSR statistically significantly lowers 7 to 18 basis points on bank loans.

In yet another study, S. Drucker and M. Puri (2009) established the fact that loans had an additional and preventive debt agreement, mainly when agency costs and information asymmetry were stricter. In prior studies, CSR has been seen to lower information asymmetry and trust (Dhaliwal et al, 2011; Cheng et al, 2014). Debt holders are exposed to a smaller threat when lending in the case when businesses undertake CSR, and they will be more liable to lend and ask for lower interest. Therefore, CSR is deemed to be able to decrease CoD. C. Demiroglu and C. M. James (2010) stipulate that the borrowers who take more risk are more prone to obtain loans with a tight agreement. S. Chava (2014) discovered that lenders charged smaller interest on bank loans to the organizations that derived significant revenue from environmentally beneficial products.

N. Attig, S. El Ghoul, O. Guedhami and J. Suh (2013) revealed the fact that CSR had a significant positive impact on a firm's credit rating. Companies proven to be highly socially performing are rewarded with high credit ratings by rating agencies. Accordingly,
CSR communicates the vital nonfinancial information which credit rating agencies use in evaluating companies. A. Goss and G. S. Roberts (2011) stipulate that with healthier credit ratings, companies can make a debt at a lower cost owing to the trust these agencies have in their operations. By implication, companies tend to engage themselves in the projects that will provide a social benefit to those concerned. Accordingly, when companies operate in a way which is perceived as socially desirable by the stakeholders, they will be able to receive high credit ratings, which may result in a lowered $\mathrm{CoD}$ in the long run.

Yet another study, namely K. M. Menz (2010), established the fact that CSR lowered CoD. It was, however, revealed that socially responsible companies received lower risk premiums. The one reason for this could be the fact that credit ratings mattered more to bond investors than CSR ratings did. His results revealed a non-positive correlation between CSR and CoD. Nevertheless, the result demonstrates that high credit ratings add value to companies' $\mathrm{CoD}$ to some extents.

\section{Theoretical Framework}

M. Friedman (1962) upholds that shareholder theory emphasizes a firm's top priority as maximizing the firm's value. Therefore, expenditures relating to CSR are conceived as a poor way to use shareholders' money, which practice digresses from shareholder value maximization theory. The theory upholds that performing CSR activities will consume the resources that otherwise might have facilitated the generation of a bigger profit for shareholders. From the point of view of shareholders, a higher performance of CSR could affect shareholders' interest. When interest is reduced, the capacity to pay or the interest in paying is also reduced, which may result in an enhanced distress risk, and both may relate to the higher costs of debt financing.

E. Freeman (1984) propounded stakeholder theory. His theory opposed shareholder theory, holding that businesses had to consider stakeholders in all facets of their operations. The theory proposed that corporations should go beyond the benefits shareholders stand to generate in order to consider 
the welfare of a broader stakeholder group in society (Freeman, 1984). T. M. Jones (1995) broadens the theory by indicating that CSR is an indispensable part for corporations to obtain the essential resources and stakeholder support. Considering the standpoint of the theory, performing CSR may result in a discount cost of acquiring capital for two reasons. The first reason is that CSR-associated facts capture the organizational environmental peril and lead to a decline in the information asymmetry. This, in return, might have an effect on CoE (Jones, 1995; Heinkel, Kraus \& Zechner, 2001; Orlitzky, Schmidt \& Rynes, 2003). According to M. Jensen and W. Meckling (1976), any information that eases information asymmetries among contracting parties and as such reduces unfavorable selection and ethical hazard problems would be value relevant.

In developed countries, the largest number of empirical papers in the literature have recorded that disclosures of financial information make available the relevant pieces of information that are of value to stakeholders, and as such shrink CoC (Diamond \& Verrecchia, 1991; Botosan, 1997; Leuz \& Verrecchia, 2000; Graham, Harvey \& Rajgopal 2005). In conformity with this argument, M. Orlitzky et al (2003) proposed that the information that related to the CSR recital was value relevant.

Performing CSR may lead to boosting the size of the investor base. Socially mindful investors choose to eliminate the firms with low CSR performance from their investment portfolios (Heinkel et al, 2001). By implication, corporations with healthy CSR performance are in advantage when increasing the comparative length in their investor bases is concerned. The healthier the size of the investor base, the lower $\mathrm{CoC}$ and the healthier the marketplace valuation (Merton, 1987).

\section{METHODOLOGY}

The sample included in the study comprises the 159 companies quoted on the NSE as of 2020. Using the nonprobability sampling technique, a sample of 32 companies with minimum one company from each of the following sectors: the Industrial Sector, the Consumer Goods Sector, the Financial Service Sector, the Health Care Sector, the Technology Sector, the Basic Material Sector, the Oil and Gas Sector, and the Consumer Services Sector was made judgmentally. The selection was based on the complete, published annual reports for the period covered. To achieve the purpose of the study, content analysis was used to collect the panel data for the variables. The study adopted the panel least square method of the random effect model to analyze the influence of CSR on the cost of capital in Nigeria.

\section{Dependent variable}

The dependent variable is the $\mathrm{CoC}$ measured using $\mathrm{CoE}$ and $\mathrm{CoD}$. Regarding $\mathrm{CoE}$, the dividend capitalization model (DCM) was used to estimate the CoE. This model is mainly applied to the companies that pay out a dividend.

The formula to compute the DCM is as follows:

$$
R_{e}=\left(D_{1} / P_{0}\right)+g
$$

where:

$$
\begin{aligned}
& R_{e}=\text { the cost of equity } \\
& D_{1}=\text { dividends per share next year } \\
& P_{0}=\text { the current share price } \\
& g=\text { the dividend growth rate. }
\end{aligned}
$$

According to Corporate Finance Institute (2021), dividend growth for each year can be achieved by applying the following equation:

$$
\text { Dividend growth }=\left(D_{1} / D_{t-1}\right)-1
$$

where:

$D_{1}=$ the dividend payment of the year $t$,

$D_{t-1}=$ the dividend payment of the year $t-1$ (one year before the year $t$ ) 


\section{Cost of debt}

$\mathrm{CoD}$ is the effective interest rate a company pays to debt holders on its current liabilities. In general, it refers to the after-tax $\mathrm{CoD}$. The difference between the before-tax cost of debt and the after-tax cost of debt depends on the interest expenses deducted. As regards $\mathrm{CoD}$, it is one minus the tax rate into interest expenses. Thus, the formula for calculating $\mathrm{CoD}$ reads as follows:

\section{CoD $=$ Interest Expenses $(1-$ Tax Rate $)$.}

\section{Independent variable}

Prior studies in Nigeria have used diverse CSR measurements. For example, A. U. Asian and T. A. Uche (2018) used dummy variables, A. T. Abideen, O. A. Abayomi and S. A. Nureni (2017) used donations made by companies to the community during the period, O. D. Adeyanju (2012) and U. O. Godwin (2012) used questionnaires, F. M. Ajide and A. A. Aderemi (2014) used the Morgan Stanley Capital International Environment Social and Governance Index (the MSCI ESG Index) - formerly the Kinder, Lydenberg, Domini Index (the KLD Index), and While, O. F. Olaoye and O. E. Oluwadare (2018) used the CSR disclosure Index. In this present study, however, the Thomson Reuther Index used by N. S. Ofogbe, C. N. EzuworeObodoekwe, A. P. Ozoji, C. Namani, C. A. Anisiuba,
I. P. Oliakor and R. Okafor (2021) was adopted. The index measures CRS via the three dimensions, namely corporate social performance (CSP), environmental performance (ENP), and corporate governance performance (CGP). Table 1 shows the scores for the different categories of the ESG scores.

\section{CONTROL VARIABLES (CVs)}

\section{Control variables - $\mathrm{CoE}$}

To recognize the effect CSR disclosure had on $\mathrm{CoE}$, some variables were used as control variables to that effect. Considering the study carried out by $\mathrm{C}$. Reverte (2012), the market-to-book value (MB), Beta (BETA), and the size of the firm (SIZE) were found to be connected with CoE. Alternatively, CoE ought to be positively correlated with the beta variable. In addition, L. Hail and C. Leuz (2006) opined that many proxies had represented the magnitude of the firm in different ways. That included the total assets, the market value of equity, the total sales, the number of the employees, and market capitalization. D. S. Dhaliwal et al (2011) conversely used the total assets logarithm to represent the size of the firm.

Regarding data availability, this study used the total assets logarithm to signify the size of the firm and the

Table 1 The Thomson Reuters indices for social, environmental, and CG performance

\begin{tabular}{l|lcc}
\hline Pillar & Category & Scoring & Weight \\
\hline \multirow{2}{*}{ Environmental performance } & Resources use & 19 & $11 \%$ \\
& Emission & 22 & $12 \%$ \\
& Innovation & 20 & $11 \%$ \\
\hline \multirow{2}{*}{ Social performance } & Workforce & 29 & $16 \%$ \\
& Human rights & 8 & $4.50 \%$ \\
& Community & 14 & $8 \%$ \\
& Product Responsibility & 12 & $7 \%$ \\
\hline \multirow{2}{*}{ Governance performance } & Management & 34 & $19 \%$ \\
& Shareholders & 12 & $7 \%$ \\
& CSR Strategy & 8 & $4.50 \%$ \\
\hline Total & & 178 & $100 \%$ \\
\hline
\end{tabular}

Source: Thomson Reuters 
market-to-book value (MBV) as CVs for CoE. The data were retrieved from the published annual reports of the companies included in the sample. The marketto-book value was calculated using the following formula:

$\mathrm{MBV}=$ share price divided by net book value per share,

where:

net book value $=$ total assets - total liabilities.

\section{Control variables - $\mathrm{CoD}$}

M. F. Izzo and B. S. Magnanelli (2012) stipulate that profitability is negatively connected with $\mathrm{CoD}$. For this reason, return on assets (ROA) is used as a proxy for profitability. Additionally, they argue that financial leverage (LEV) and Beta (BETA) are positively correlated with CoD. In that regard, and based on data availability, ROA and leverage are used as CVs for $\mathrm{CoD}$. Leverage is derived by means of dividing the total debt by the market value of equity, whereas return on assets is computed using the formula stated below:

\section{$\mathrm{ROA}=$ net income/average total asset.}

To calculate a company's ROA, it is more accurate to use the average total assets. This is necessary as a company's total assets can change over a period, which may be due to the purchase or sale of fixed assets, such as vehicles, land, and equipment. Consequently, the calculation of the average total assets is more accurate than the total assets for one particular period (Claire Boyte-White, 2021).

\section{Model specification}

The functional relationship between CSR and COC; $\mathrm{COE}$, and COD can be identified as follows:

$$
y_{i-t}=\beta_{0}+\beta_{1} X_{i-t}+\beta_{2} X_{i-t}+\beta_{3} X_{i-t}+\beta_{4} X_{i-t}+\beta_{5} X_{i-t}+\mu_{i-t}
$$

Hypothesis 1

$$
\begin{aligned}
& \text { COE }=\beta_{0}+\beta_{1} \operatorname{CSP}_{i-t}+\beta_{2} E P_{i-t}+\beta_{3} \operatorname{CGP}_{i-t}+\beta_{4} \\
& \text { LOGFSIZ }_{i-t}+\beta_{5} M B V_{i-t}+\mu_{i-t}
\end{aligned}
$$

Hypothesis 2

$$
\begin{aligned}
& C O D=\beta_{0}+\beta_{1} \operatorname{CSP}_{i-t}+\beta_{2} E P_{i-t}+\beta_{3} \operatorname{CGP}_{i-t}+\beta_{4} R O A_{i-t}+ \\
& \beta_{5} L E V_{i-t}+\mu_{i-t}
\end{aligned}
$$

where:

$y_{i-t}=$ the dependent variable

$\beta_{0}=$ the intercept of the equation

$\beta_{1}-\beta_{5}=$ the coefficients of the $\mathrm{Xi}$ - $\mathrm{t}$ variable

$X_{i-t}=$ the independent variable

$I=$ the cross-section variables of the companies included in the sample

$T=$ the study period

$\mu=$ the error term

The estimation procedure: The estimation process follows a collection of the pre-estimation tests, diagnostics tests and panel estimation tests. A choice of the fixed effect and random effect regression model depends on the Haussmann test carried out on the panel data.

\section{Data Analysis and Results}

Considering the data obtained from the companies' published financial statements from 2005 to 2019, covering a period of 15 years of observation, a total of 480 observation data were collected.

\section{Pre-test Descriptive Statistics (DS)}

Table 2 shows the results of the DS for all the variables from 2005 to 2019.

Table 2 shows the result of the descriptive statistics of the individual variables respectively. Regarding the $\mathrm{CoC}, \mathrm{CoE}$ and $\mathrm{CoD}$, the arithmetic mean is 12.624 and 5.834, respectively. By implication, the cost of financing the debt is moderately expensive. For CSP, ENP and CGP, the mean scores are 33.875, 23.952, and 32.844 , respectively. By implication, the analysis 
Table 2 The descriptive statistics

\begin{tabular}{l|ccccccccc}
\hline & COE & LCOD & CSP & ENP & CGP & LFIRMSIZ & MBV & ROA & LEV \\
\hline Mean & 5.834 & 12.624 & 33.875 & 23.952 & 32.842 & 16.798 & 3.785 & 0.168 & 5.880 \\
Median & 1.342 & 12.455 & 35.000 & 24.000 & 34.000 & 17.008 & 2.995 & 0.077 & 1.750 \\
Maximum & 283.000 & 20.442 & 47.000 & 43.000 & 54.000 & 23.039 & 9.970 & 4.652 & 680.144 \\
Std. Dev. & 19.569 & 2.759 & 9.198 & 8.050 & 10.238 & 2.340 & 2.414 & 0.316 & 35.727 \\
Skewness & 9.404 & 0.064 & -1.675 & 0.012 & -1.577 & -0.152 & 0.756 & 8.317 & 16.033 \\
Kurtosis & 113.039 & 2.638 & 6.779 & 2.482 & 6.444 & 2.799 & 2.469 & 101.816 & 282.879 \\
Jarque-Bera & 2492447 & 2.944 & 510.11 & 5.384 & 436.01 & 2.649 & 51.297 & 2008259 & 1583903 \\
\hline Observations & 480 & 479 & 480 & 480 & 480 & 478 & 480 & 480 & 479 \\
\hline
\end{tabular}

Source: Authors

shows a healthier performance of CSR. The standard deviation values are small compared to the mean. This means the values in the statistical set are close to the mean of the data set. All the variables demonstrate a positive value for the kurtosis with the values smaller or greater than three. These reveal the fact that the degree of the tailedness of all the variables except LCOD, ENP and LFIRMSIZ has a heavier tail, which is called a leptokurtic distribution. LCOD, ENP, MBV and LFIRMSIZ have a lighter tail, which is called platykurtosis.

Table 3 demonstrates the results of the Pearson correlation among the proxies of $\mathrm{CoC}, \mathrm{CSR}$, and the control variables. CSP is negative and does not significantly correlate with CoE but does significantly correlate with LCoD (-0.014 and 0.004). CSP is also found to be positive and not to significantly correlate with ENP. ENP is both negative/positive and does not substantially correlate with CoE, LCoD and CSP. CGP is positive and significantly correlates with CSP and ENP but does not substantially correlate with $\mathrm{CoE}$ and LCoD. CGP negatively and significantly correlates with $\mathrm{CoE}$ and $\mathrm{LCoD}$ but does not significantly correlate with CSP and ENP. Several control variables correlate with the cost of capital variables. No high correlation was found among the explanatory variables, which suggests that multicollinearity is not a serious concern in this study.

The panel unit root test summary methods were applied. Table 4 shows the results of the unit root test.
All the variables are stationary at the levels and at the first difference. This prompts the study to proceed to do the Haussmann test. The Haussmann test is meant to select the best model for each of the hypotheses.

\section{Panel Regression Analysis}

Hypothesis 1: CSR correlates with the CoE of the companies listed on the NSE.

To make a decision on the appropriate model for this hypothesis, the random and fixed effect variants of the panel data were considered side by side using the Haussmann test. The Haussmann test hypothesis reads as follows:

H0: The random effect model is appropriate.

H1: The fixed effect model is suitable.

If the p-value < 5\%, reject the null hypothesis; otherwise, accept the alternative hypothesis.

Table 5 shows the result of the Haussmann test hypothesis. The 5-degree-freedom cross-section chisquare statistics are 4.86 and $p=0.433$. Since $p>5 \%$, the null hypothesis is accepted for the Hypothesis 2 . In conclusion, the random effect model is a better option than the fixed effect model (Ofogbe et al, 2021).

The panel random effect regression outcomes are as shown in Table $6 . \mathrm{R}^{2}$ of $2.3 \%$ shows that the panel regression fits in well. The exogenous variables mutually account for a $2.3 \%$ variation in the 
Table 3 The Pearson correlation matrix among the variables

\begin{tabular}{|c|c|c|c|c|c|c|c|c|c|}
\hline & $\mathrm{COE}$ & LCOD & CSP & ENP & CGP & LFIRMSIZ & MBV & ROA & LEV \\
\hline $\mathrm{COE}$ & 1.00000 & & & & & & & & \\
\hline LCOD & $\begin{array}{l}0.039^{*} \\
(0.387)\end{array}$ & 1.000000 & & & & & & & \\
\hline CSP & $\begin{array}{l}-0.014^{*} \\
(0.757)\end{array}$ & $\begin{array}{l}0.004^{* *} \\
(0.0715)\end{array}$ & 1.00000 & & & & & & \\
\hline ENP & $\begin{array}{l}-0.072^{*} \\
(0.114)\end{array}$ & $\begin{array}{c}0.001^{*} \\
(0.9818)\end{array}$ & $\begin{array}{l}0.029^{*} \\
(0.5271)\end{array}$ & 1.0000 & & & & & \\
\hline CGP & $\begin{array}{l}0.041^{*} \\
(0.367)\end{array}$ & $\begin{array}{c}0.932^{*} \\
(0.9818)\end{array}$ & $\begin{array}{l}0.586 * * \\
(0.0000)\end{array}$ & $\begin{array}{l}0.105^{*} \\
(0.0217)\end{array}$ & 1.0000 & & & & \\
\hline LFIRMSIZ & $\begin{array}{l}0.089 * * \\
(0.053)\end{array}$ & $\begin{array}{l}0.752^{* * *} \\
(0.0000)\end{array}$ & $\begin{array}{l}-0.049^{*} \\
(0.2788)\end{array}$ & $\begin{array}{c}0.049^{*} \\
(0.2862)\end{array}$ & $\begin{array}{c}-0.047^{*} \\
(0.3089)\end{array}$ & 1.00000 & & & \\
\hline MBV & $\begin{array}{l}0.069^{*} \\
(0.132)\end{array}$ & $\begin{array}{l}-0.053^{*} \\
(0.2484)\end{array}$ & $\begin{array}{c}0.022^{*} \\
(0.6313)\end{array}$ & $\begin{array}{c}0.048^{*} \\
(0.2994)\end{array}$ & $\begin{array}{c}0.047^{*} \\
(0.3088)\end{array}$ & $\begin{array}{c}0.002^{*} \\
(0.9729)\end{array}$ & 1.00000 & & \\
\hline ROA & $\begin{array}{l}-0.040^{*} \\
(0.3817)\end{array}$ & $\begin{array}{l}-0.007^{*} \\
(0.8709)\end{array}$ & $\begin{array}{c}-0.001^{*} \\
(0.9795)\end{array}$ & $\begin{array}{l}-0.069^{*} \\
(0.1297)\end{array}$ & $\begin{array}{l}-0.099^{* *} \\
(0.0302)\end{array}$ & $\begin{array}{l}-0.086 * * \\
(0.0607)\end{array}$ & $\begin{array}{c}0.013^{*} \\
(0.7775)\end{array}$ & 1.00000 & \\
\hline LEV & $\begin{array}{l}0.094^{* *} \\
(0.0407)\end{array}$ & $\begin{array}{l}0.181 * * * \\
(0.0001)\end{array}$ & $\begin{array}{c}-0.150^{* * *} \\
(0.0010) \\
\end{array}$ & $\begin{array}{r}-0.098^{* *} \\
(0.0319) \\
\end{array}$ & $\begin{array}{l}-0.195^{* * *} \\
(0.0000) \\
\end{array}$ & $\begin{array}{l}0.158^{* * *} \\
(0.0005) \\
\end{array}$ & $\begin{array}{c}-0.012^{*} \\
(0.7937) \\
\end{array}$ & $\begin{array}{c}-0.003^{*} \\
(0.9504) \\
\end{array}$ & 1.0000 \\
\hline
\end{tabular}

(i) Variable Construe: the cost of equity (COE), the log of $\operatorname{COD}(\mathrm{LCOD})$, corporate social performance (CSP), environmental performance (ENP), corporate governance performance (CGP), the log of the firm size (LFIRMSIZ), the market-to-book value (MBV), return on assets (ROA) and leverage (LEV).

(ii) P-values in parenthesis; ${ }^{*} p<0.10, * * p<0.05,{ }^{* * *} p<0.01$

Source: Authors

Table 4 The summary of the panel unit root test

\begin{tabular}{|c|c|c|c|c|c|}
\hline Variables & Levin, Lin \& Chu t & $\begin{array}{c}\text { Im, Pesaran and } \\
\text { Shin W-stat }\end{array}$ & $\begin{array}{c}\text { ADF - Fisher Chi- } \\
\text { square }\end{array}$ & $\begin{array}{c}\text { PP - Fisher Chi- } \\
\text { square } \\
\end{array}$ & Status \\
\hline $\mathrm{COE}$ & $\begin{array}{c}-26.1006 * * * \\
(0.0000)\end{array}$ & $\begin{array}{c}-9.09385^{* * *} \\
(0.0000)\end{array}$ & $\begin{array}{c}154.784^{* * *} \\
(0.0011)\end{array}$ & $\begin{array}{c}246.747^{* * *} \\
(0.0000)\end{array}$ & $1(0)$ \\
\hline LCOD & $\begin{array}{c}-11.0390^{* *} \\
(0.0322)\end{array}$ & $\begin{array}{c}-8.13000 * * * \\
(0.0000)\end{array}$ & $\begin{array}{c}188.976 * * * \\
((0.0066)\end{array}$ & $\begin{array}{c}410.870 * * * \\
(0.0000)\end{array}$ & $1(0)$ \\
\hline CPS & $\begin{array}{c}-1.29763^{* *} \\
(0.0972)\end{array}$ & $\begin{array}{c}-3.25021^{* * *} \\
(0.0006)\end{array}$ & $\begin{array}{c}98.3057^{* * *} \\
(0.0038)\end{array}$ & $\begin{array}{c}214.417^{* * *} \\
(0.0000)\end{array}$ & $1(0)$ \\
\hline ENP & $\begin{array}{c}-6.51652^{* * *} \\
(0.0000)\end{array}$ & $\begin{array}{c}-9.16233^{* * *} \\
(0.0017)\end{array}$ & $\begin{array}{c}203.642^{* * *} \\
(0.0005)\end{array}$ & $\begin{array}{c}203.642^{* * * *} \\
(0.0000)\end{array}$ & $1(1)$ \\
\hline CGP & $\begin{array}{c}-7.67429 * * * \\
(0.0000)\end{array}$ & $\begin{array}{c}-8.43960 * * * \\
(0.0000)\end{array}$ & $\begin{array}{c}189.210^{* * * *} \\
(0.0000)\end{array}$ & $\begin{array}{c}489.592^{* * *} \\
(0.0000)\end{array}$ & $1(1)$ \\
\hline LFIRMSIZ & $\begin{array}{c}-27.7669 * * * \\
(0.0000)\end{array}$ & $\begin{array}{c}-5.93797^{* * *} \\
(0.0032)\end{array}$ & $\begin{array}{c}92.5118^{* *} \\
(0.0114)\end{array}$ & $\begin{array}{c}102.638 * * * \\
(0.0016)\end{array}$ & $1(1)$ \\
\hline MBV & $\begin{array}{c}-16.9331 * * * \\
(0.0000)\end{array}$ & $\begin{array}{c}-12.1742^{* * * *} \\
(0.0052)\end{array}$ & $\begin{array}{c}239.945^{* * *} \\
(0.0017)\end{array}$ & $\begin{array}{l}421.513 * * * \\
(0.0000)\end{array}$ & $1(1)$ \\
\hline ROA & $\begin{array}{c}-19.7947^{* * * *} \\
(0.0000)\end{array}$ & $\begin{array}{c}-5.51149^{* * * *} \\
(0.0000)\end{array}$ & $\begin{array}{c}110.923^{* * * *} \\
(0.0003)\end{array}$ & $\begin{array}{l}219.401 * * * \\
(0.0000)\end{array}$ & $1(1)$ \\
\hline LEV & $\begin{array}{c}-582.245^{* * *} \\
(0.0000)\end{array}$ & $\begin{array}{c}-92.8617^{* * *} \\
(0.0000)\end{array}$ & $\begin{array}{c}177.392^{* * *} \\
(0.0000)\end{array}$ & $\begin{array}{c}383.509 * * * \\
(0.0000)\end{array}$ & $1(1)$ \\
\hline
\end{tabular}

P-values is in parenthesis: the result is at $1 \%, 5 \%$ and $10 \%$ significance levels

Source: Authors 
Table 5 The Haussmann test for Model One

\begin{tabular}{l|ccc}
\hline \multicolumn{4}{|c}{ Model One } \\
\hline Test summary & $\begin{array}{c}\text { Chi-Sq. } \\
\text { Statistic }\end{array}$ & Chi-Sq. d.f. & Prob. \\
$\begin{array}{l}\text { Cross-section } \\
\text { random }\end{array}$ & 4.858 & 5 & 0.4334 \\
\hline
\end{tabular}

Source: Authors

Table 6 CSR correlates with the CoE of the companies listed on the NSE

\begin{tabular}{l|cccc}
\hline Variables & Coefficient & Std Error & t-statistics & Pro. \\
\hline CSP & -0.134891 & 0.120928 & -1.115459 & 0.2652 \\
ENP & -0.198236 & 0.111648 & -1.775541 & 0.0765 \\
CGP & 0.178409 & 0.109324 & 1.631922 & 0.1034 \\
LFIRMSIZ & 0.789618 & 0.382438 & 2.064697 & 0.0395 \\
MBV & -0.527425 & 0.371752 & -1.418754 & 0.1566 \\
C & -1.953468 & 7.890879 & -0.247560 & 0.8046 \\
R & $2.3 \%$ & & & \\
Adjusted & $1.3 \%$ & & & \\
R-square & & & & \\
F- stat & $2.24 \%$ & & & \\
P-value & 0.049318 & & & \\
D.W stat & 11.83 & & & \\
\hline
\end{tabular}

Source: Authors

endogenous variable with an unexplained variation of $97.7 \%$. This implies that the other variables are responsible for the variation in the endogenous variable not accounted for. CSP and ENP are negative and are not significantly associated with CoE. By implication, CSP and ENP have not led to better access to capital at a reduced cost. The findings support shareholder theory which emphasizes the fact that the higher performance of CSR could affect shareholders' interest. The company's main interest is to maximize the value of the firm. This study is also in line with the findings by K. M. Menz (2010), whose study fails to establish the fact that CSR lowers CoD. CGP has a positive non-significant effect on $\mathrm{CoD}$. For the CVs, LFIRMSIZ is positive and significantly correlates with $\mathrm{CoD}$, whereas the MBV is negative and fails to correlate with $\mathrm{CoE}$.

Although $\mathrm{R}^{2}$ is small, it cannot discredit the result because, on the whole, the result of the panel regression is significant. This is shown by the F-stat 2.24, the p-value 0.049318, and the Durbin Watson Statistics 1.8, which is approximately 2 . This outcome rules out the likelihood of the suspicion of the firstorder positive autocorrelation. These figures are the pointers indicating that the obtained result is reliable for a meaningful analysis.

Hypothesis 3: CSR correlates with the $\mathrm{CoD}$ of the companies quoted on the NSE.

Table 7 shows the result of the Haussmann test. Based on the result, the random effect model is a better option than the fixed effect model.

Table 7 The Haussmann test for Model Two

\begin{tabular}{l|ccc}
\hline \multicolumn{4}{|c}{ Model One } \\
\hline Test summary & $\begin{array}{l}\text { Chi-Sq. } \\
\text { Statistic }\end{array}$ & Chi-Sq. d.f. & Prob. \\
$\begin{array}{l}\text { Cross-section } \\
\text { random }\end{array}$ & 6.161020 & 5 & 0.2909 \\
\hline
\end{tabular}

Source: Authors

The regression results for the hypothesis two are as shown in Table $8 . \mathrm{R}^{2} 4.4 \%$ shows how the panel regression fitted in well. The exogenous variables are jointly responsible for a $4.4 \%$ variation in the endogenous variable with an unexplained variation of $95.6 \%$. CSP is negatively and significantly correlated with $\mathrm{CoD}$, which implies that an increase in the CSP scores will lead to a decrease in CoD. ENP has a positive non-significant correlation with $\mathrm{CoD}$.

This means ENP has not led to a reduction in the cost of obtaining capital. CGP has a significant positive association with $\mathrm{CoD}$. This implies that, regarding CSR, the policies in place lead to better debt options and also reduce $\mathrm{CoD}$. This result supports A. Goss and G. S. Robert (2011) and S. Chava (2014). Their studies revealed that CSR significantly lowered bank loans. 
Table 8 CSR correlates with the COD of listed companies in NSE

\begin{tabular}{l|cccc}
\hline Variables & Coefficient & Std Error & t-statistics & Pro. \\
\hline CSP & -0.036982 & 0.016969 & -2.179379 & 0.0298 \\
ENP & 0.003537 & 0.015591 & 0.226881 & 0.8206 \\
CGP & 0.030548 & 0.015455 & 1.976622 & 0.0487 \\
ROA & 0.033327 & 0.396932 & 0.083962 & 0.9331 \\
LEV & 0.014297 & 0.003562 & 4.013464 & 0.0001 \\
C & 12.70244 & 0.637232 & 19.93377 & 0.0000 \\
R & $4.4 \%$ & & & \\
Adjusted & $3.4 \%$ & & & \\
R-square & & & & \\
F-stat & $4.36 \%$ & & & \\
P-value & 0.000682 & & & \\
D.W stat & 11.53 & & & \\
\hline
\end{tabular}

Source: Authors

For the CVs, ROA is positive and non-significantly correlated with CoD while LEV is positive and significantly correlated with $\mathrm{CoD}$.

Although $\mathrm{R}^{2}$ is small, it cannot discredit the result because, on the whole, the result is significant. This is shown by the F-stat 4.36, $\mathrm{p}=0.000682$, and the Durbin Watson Statistics 1.5, which is approximately 2. This outcome rules out the likelihood of the suspicion of the first-order positive autocorrelation. These figures are the pointers that indicate the fact that this result is reliable for a meaningful analysis.

To further support the consistency of the data set, a normality (diagnostic) test was conducted. This was done in order to confirm that there were no violations of the assumption of the regression model. Such a violation would cause doubts regarding the validity and reliability of the regression model. The result is proven in Figure 1.

\section{Diagnostic test}

The above result is presented by the histogram and DS of the data set, including the Jarque-Bera statistics for testing normality. The rule is that, if data sets are normally distributed, the histogram should be bellshaped, and the Jarque-Bera statistics must not be significant at $5 \%$ levels.

Figure 1 reveals the fact that the non-normality hypothesis is accepted since the p-value of the JarqueBerra statistics $>0.05$; $(0.795967)$ and the histogram is bell-shaped. It is therefore concluded that the data set is normally distributed and can be used to carry out a meaningful analysis.

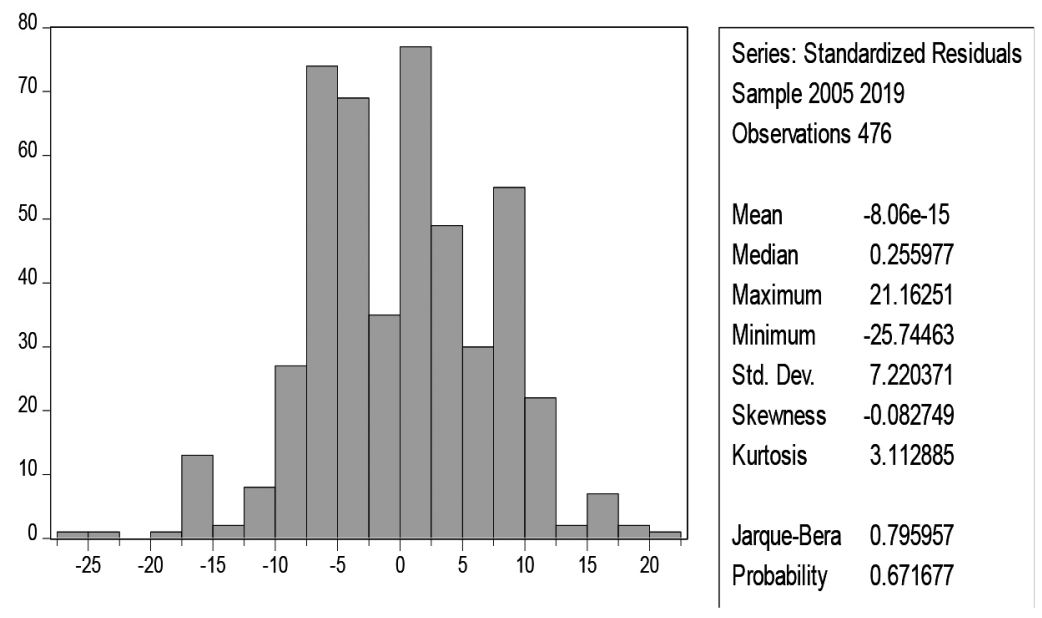

Figure 1 The normality assumption test

Source: Authors 


\section{CONCLUSION}

This study explored the effect of CSR on the CoC of the selected companies quoted on the NSE for a period of 15 years, namely from 2005 to 2019. Yearly panel data were used. The data were analyzed using descriptive statistics, the correlation matrix, the unit root test and the random effect model. To make a decision on an appropriate model for this hypothesis, the random and fixed effect variants of the panel data were considered side by side using the Haussmann test. The general result of the study revealed that CSR had an influence on the $\mathrm{CoC}$ of the selected companies in Nigeria. In conformity with the studies carried out in the developed world, namely K. M. Menz (2010); A. Goss and G. S. Robert (2011) and S. Chava (2014), mixed results were obtained.

For the first hypothesis, the general result shows a significant correlation between CSR and the cost of equity, This shows to a great extent that performing CSR has led to the better options for obtaining capital at a reduced cost.

For the second hypothesis, although the individual effect of the different dimensions of CSR differs, there is strong evidence that performing CSR in the course of doing business has noticeably led to a better option for accessing capital at a reduced interest rate. These findings support the findings of the largest number of international empirical studies, among which some may be mentioned O. Youngkyung and K. Jungmu (2019).

The significant impact of the CSR dimension on CoC implies that the companies included in the study sample for the studied period engaged themselves in CSR practice and, as a result, accessed capital with ease and at a reduced cost. In other words, CSR initiatives can attract funding whether these activities are routed through stakeholders or not.

The findings have a practical inference. The result will spur those companies that are not CSRcompliant to adopt CSR as a part of their day-to-day operations and motivate CSR-compliant companies to dedicate more attention to CSR issues. That is, its outcome is helpful to the organizations practicing CSR, those yet to adopt CSR, and stakeholders as well.
To conclude, the companies that invest in CSR have a better chance of accessing funds at a better and low cost.

Based on the findings, the study advocates continuous investment on the issues that concern CSR as these will, if consistent, lead to easy access to capital and at a reduced cost.

Notwithstanding the effort this study has made, the same is limited by the number of the companies included in the sample. For instance, out of the 159 companies quoted on the NSE, only 32 have complete reports for the studied period of 15 years.

To extend the discourse, it is suggested that further studies should adopt other measures for CSR, such as the amount of data and information disclosed in the annual report and the KLD Index in future research. Also, the relationship between social responsibility disclosure and the stock price can also be considered. Therefore, future studies should consider this matter.

\section{REFERENCES}

Abdulaziz, A. (2018). Corporate social responsibility: Concepts, perspectives, and link with corporate performance: Literature review. International Journal of Business and Management Review, 6(2), 1-14.

Abideen, A. T., Abayomi, O. A., \& Nureni, S. A. (2017). Effects of corporate social responsibility on banks FP in Nigeria: A study of United bank of Africa. International Journal of Business, Economics and Management 4(6), 136-147. doi:10.18488/journal.62.2017.46.136.147

Adeyanju, O. D. (2012). An assessment of the impact of corporate social responsibility on Nigerian society: The examples of banking and communication industries. Universal Journal of Marketing and Business Research, 1(1), 1743.

Agbiogwu, A. A., Ihendinihu, J. U., \& Okafor, M. C. (2016). Impact of environmental and social costs on performance of Nigerian manufacturing companies, International Journal of Economics and Finance, 8(9), 173-180. doi:10.5539/ijef. v8n9p173 
Ajide, F. M., \& Aderemi, A. A. (2014). The effects of corporate social responsibility activity disclosure on corporate profitability: Empirical evidence from Nigerian commercial banks. IOSR Journal of Economics and Finance, 2(6), 17-25. doi:10.9790/5933-0261725

Allen, G., \& Gordon, S. R. (2011). The impact of corporate social responsibility on the cost of bank loans. Journal of Banking E Finance, 35(7), 1794-1810. doi:10.1016/j.jbankfin.2010.12.002

Ansong, A., Agyei, S. K., \& Marfo-Yiadom, E. (2017). Do lenders value firm reputation? Evidence from SMEs in Ghana. EuroMed Journal of Management, 2(2), 152-163. doi.org/10.1504/EMJM.2017.085874

Asian A. U., \& Uche, T. A. (2018). Financial performance and corporate social responsibility of quoted firms in Nigeria. International Journal of Innovative Social Sciences \& Humanities Research, 6(1), 14-30.

Attig, N., El Ghoul, S., Guedhami, O., \& Suh, J. (2013). Corporate social responsibility and credit ratings. Journal of business ethics, 117(4), 679-694. doi:10.1007/s10551-013-1714-2

Banerjee, S. B. (2008). Corporate social responsibility: The good, the bad, and the ugly. Critical Sociology, 34(1), 51-79. doi.org/10.1177/0896920507084623

Barbara, S. M., \& Maria, F. I. (2017). Corporate social performance and cost of debt: The relationship. Social Responsibility Journal, 13(2), 250-265. doi:10.1108/SRJ-06-20160103

Basu, K., \& Palazzo, G. (2008). Corporate social responsibility: A process model of sensemaking. Academy of Management Review, 33(1), 122-136. doi.org/10.2307/20159379

Botosan, C. A. (1997). Disclosure level and the cost of equity capital. The Accounting Review, 72(3), 323-349.

Chava, S. (2014). Environmental externalities and cost of capital. Management Science, 60(9), 2223-2247. doi.org/10.1287/ mnsc.2013.1863

Cheng, B., Ioannou, I., \& Serafeim, G. (2014). Corporate social responsibility and access to finance. Strategic Management Journal, 35(1), 1-23. doi.org/10.1002/smj.2131

Chin-Chen Y., Fengyi, L., Teng-Shih, W., \& Chia-Ming, W. (2020). Does corporate social responsibility affect cost of capital in China? Asia Pacific Management Review, 25(1), 1-12. doi:10.1016/j.apmrv.2019.04.001
Claire Boyte-White. (2021). Guide to financial Ratio, Investopedia. Retrieved April 18, 2021, from https://www.investopedia. com/ask/answers/031215/what-formula-calculating-returnassets-roa.asp

Corporate Finance Insitute. (2021). Cost of Equity Formula. Retrieved January 15, 2021, from https:// corporatefinanceinstitute.com/resources/knowledge/ finance/cost-of-equity-guide/

Demiroglu, C., \& James, C. M. (2010). The information content of bank loan covenants. Review of financial Studies, 23(10), 3700-3737.

Denis, D. J., \& Mihov, V. T. (2003). The choice among bank debt, non-bank private debt, and public debt: Evidence from new corporate borrowings. Journal of Financial Economics, 70(1), 3-28. doi.org/10.1016/S0304-405X(03)00140-5

Dhaliwal, D. S., Li, O. Z., Tsang, A., \& Yang, Y. G. (2011). Voluntary nonfinancial disclosure and the cost of equity capital: The initiation of corporate social responsibility reporting. The Accounting Review, 86(1), 59-100. doi.org/10.2308/accr.00000005

Diamond, D., \& Verrecchia, R. (1991). Disclosure, liquidity, and the cost of capital. Journal of Finance, 46(4), 1325-1359. doi.org/10.1111/j.1540-6261.1991.tb04620.x

Drucker, S., \& Puri, M. (2009). On loan sales, loan contracting, and lending relationships. Review of Financial Studies, 22(7), 2835-2872. doi.org/10.1093/rfs/hhn067

Dubbink, W., Graafland, J., \& Van Liedekerke, L. (2008). Corporate social responsibility, transparency and the role of intermediate organisations. Journal of Business Ethics, 82(2), 391-406. doi:10.1007/s10551-008-9893-y

Dugger, W. M. (1989). Corporate Hegemony. Santa Barbara, CA: Greenwood Publishing Group.

Ehioghiren, E. E., \& Eneh, O. (2019). Corporate social responsibility accounting and financial performance of insurance companies in Nigeria. International Journal of Academic Accounting, Finance \& Management Research, 3(5), $16-25$.

Ernst \& Young (2013). The Value of Sustainability Reporting. Retrieved January 5, 2015, from http://www.ey.com/US/ en/Services/SpecialtyServices/Climate-Change-andustainability-Services/Value-of-sustainability-reporting.

Freeman, E. (1984). Strategic Management: A Stakeholder Approach. Cambridge, MA: Cambridge University Press. 
Friedman, M. (1962). Capitalism and Freedom. Chicago, IL: University of Chicago Press.

Godwin, U. O. (2012). Community perception and oil companies corporate social responsibility initiative in the Niger Delta. Studies in Sociology of Science, 3(4), 11-21, doi:10.3968/j.sss.1923018420120304.600

Goss, A., \& Roberts, G. S. (2011). The impact of corporate social responsibility on the cost of bank loans. Journal of Banking \& Finance, 35(7), 1794-1810. doi.org/10.1016/j. jbankfin.2010.12.002

Graham, J. R., Harvey, C. R., \& Rajgopal, S. (2005). The economic implications of corporate financial reporting. Journal of Accounting and Economics, 40(1-3), 3-73. doi:10.1016/j. jacceco.2005.01.002

Hail, L., \& Leuz, C. (2006). International differences in the cost of equity capital: do legal institutions and securities regulation matter? International cost of equity capital. Journal of Accounting Research, 44(3), 485-531. doi.org/10.1111/ j.1475-679X.2006.00209.x

Hawn, O., Chatterji, A., \& Mitchell, W. (2011). How operational legitimacy conditions the impact of changes in social legitimacy on firm's economic value: The Dow Jones sustainability index addition and deletion. Working paper 11/2011. Duke University.

Healy, P. M., \& Palepu, K. G. (2001). Information asymmetry, corporate disclosure, and the capital markets: A review of the empirical disclosure literature. Journal of Accounting and Economics, 31(1-3), 405-440. doi.org/10.1016/S01654101(01)00018-0

Heinkel, R., Kraus, A., \& Zechner, J. (2001). The effect of green investment on corporate behaviour. The Journal of Financial and Quantitative Analysis, 36(4), 431-449. doi.org/10.2307/2676219

Izzo, M. F., \& Magnanelli, B. S. (2012). Does it pay or does the firm pay? The relation between CSR performance and the cost of debt. Retrieved April 12, 2021, from https://papers. ssrn.com/soL3/papers.cfm?abstract_id=1986131

Jensen, M., \& Meckling, W. (1976). Theory of the firm: Managerial behavior, agency costs, and ownership structure. Journal of Financial Economics, 3(4), 305-360. doi.org/10.1016/0304-405X(76)90026-X

Joëla, M. A. J. (2017). The effect of corporate social responsibility on the cost of equity from a legal origin and cultural perspective. University of Groningen and Uppsala University.
Jones, T. M. (1995). Instrumental stakeholder theory: A synthesis of ethics and economics. Academy of management review, 20(2), 404-437. doi.org/10.2307/258852

Joseph, U. M., \& Michah, C. O. (2016). Impact of corporate social responsibility on financial performance: Evidence from listed banks in Nigeria. Expert Journal of Finance, 4, 1-9.

Krishnaswami, S., Spindt, P. A., \& Subramaniam, V. (1999). Information asymmetry, monitoring, and the placement structure of corporate debt. Journal of Financial Economics, 51(3), 407-434.

Lee, M. -D. P. (2008). A review of the theories of corporate social responsibility: Its evolutionary path and the road ahead. International Journal of Management Reviews, 10(1), 5373. doi.org/10.1111/j.1468-2370.2007.00226.x

Leland, H. E., \& Pyle, D. H. (1977). Informational asymmetries, financial structure, and financial intermediation. Journal of Finance, 32(2), 371-387. doi.org/10.2307/2326770

Leuz, C., \& Verrecchia, R. (2000). The economic consequences of increased disclosure. Journal of Accounting Research, 38, 91124. doi.org/10.2307/2672910

Menz, K. M. (2010). Corporate social responsibility: Is it rewarded by the corporate bond market? A critical note. Journal of Business Ethics, 96(1), 117-134. doi:10.1007/s10551010-0452-y

Merton, R.,(1987). A simplemodel of capitalmarketequilibrium with incomplete information. Journal of Financial Economics, 42(3), 483-510. doi.org/10.1111/j.1540-6261.1987.tb04565.x

Moskowitz, M. (1972). Choosing socially responsible stocks. Business and Society, 1(1), 71-75.

Odunayo, F. O., \& Ibidolapo, E. A. (2018). Corporate social responsibility on the performance of private telecommunication in Nigeria. Canadian Social Science, 14(8), 45-54. doi:10.3968/10511

Ofogbe, N. S., Ezuwore-Obodoekwe, C. N., Ozoji, A. P., Namani, C., Anisiuba, C. A., Oliakor, I. P., \& Okafor, R. (2021). Impact of environmental, social, and governance dimension of corporate social responsibility on firm performance: Evidence from Nigeria. Humanities and Social Sciences Letters, 9(2), 220-236, doi:10.18488/ journal.73.2021.92.220.236 
Olaoye, O. F., \& Oluwadare, O. E. (2018). Corporate social responsibility and stock price market of selected listed companies in Nigeria. International Journal of Academic Research in Business and Social Sciences, 8(7), 872-886. doi:10.6007/IJARBSS/v8-i7/4425

Orlitzky, M., Schmidt, F., \& Rynes, S. (2003). Corporate social and financial performance: A meta-analysis. Organization Studies, 24(3), 403-441. doi:10.1177/0170840603024003910

Reverte, C. (2012). The impact of better corporate social responsibility disclosure on the cost of equity capital. Corporate Social Responsibility and Environmental Management, 19(5), 253-272. doi.org/10.1002/csr.273

Smith, N. C. (2003). Corporate social responsibility: Whether or how? California Management Review, 45(4), 52-76. doi:10.2307/41166188

Stephen, E., \& Rebecca, O. D. (2018). Corporate social responsibility and Bank Performance in Nigeria. Sriwijaya International Journal of Dynamic Economics and Business, 2(4), 317-330, doi.org/10.9259/sijdeb.v2i4.317-330.

Thomson Reuters. (2017). Thomson Reuters ESG Score. Data fact sheet. Retrieved January 24, 2021, from https://financial. thomsonreuters.com/content/dam/openweb/documents/ pdf/financial/esg-scores-factsheet.pdf
Votaw, D. (1973). Genius becomes rare. In D. Votaw, \& S. P. Sethi (Eds.). The Corporate Dilemma: Traditional values versus contemporary problems (pp. 11-45). New Jersey, NJ: Prentice Hall.

Walker, K., \& Wan, F. (2012). The harm of symbolic actions and green-washing: Corporate actions and communications on environmental performance and their financial implications. Journal of Business Ethics, 109(2), 227-242. doi:10.1007/s10551-011-1122-4

Weber, M. (2008). The business case for corporate social responsibility: A company level measurement approach for CSR. European Management Journal, 26(4), 247-261. doi.org/10.1016/j.emj.2008.01.006

Wekesa, R. N. (2017). Corporate social responsibility and financial performance: The case of Safaricom Ltd. International Journal of Finance and Accounting, 6(6), 167-171. doi.10.5923/j.ijfa.20170606.02

Youngkyung, O., \& Jungmu, K. (2019). Which corporate social responsibility performance affects the cost of equity? Evidence from Korea. Sustainability, 11(10), 1-14. doi:10.3390/ su11102947

Received on $3^{\text {rd }}$ Jun 2021, after revision, accepted for publication on $25^{\text {th }}$ November 2021 Published online on $6^{\text {th }}$ December 2021 
Nyore Sandra Ofogbe, Ph.D., is a fresh graduate of the Accountancy Department. She obtained her Ph.D. Degree in Accounting at the University of Nigeria Nsukka.

Chidiebere Nnamani obtained his Ph.D. in Accounting, University of Nigeria, Nsukka. He is a lecturer in the Department of Accountancy, University of Nigeria, Nsukka.

Chika Anastesia Anisiuba is a lecturer in the Department of Accountancy, University of Nigeria, Enugu Campus. She is a Certified National Accountant (CNA), an active member of the Association of National Accountants of Nigeria (ANAN), and an Associate member of the National Institute of Management and Society for Forensic Accounting and Fraud Prevention.

Charity Nkeiru Ezuwore-Obodoekwe is a lecturer in the Department of Accountancy, University of Nigeria. She has obtained several academic degrees and professional certificates in Accountancy within and outside the shores of Nigeria. 


\title{
VEZA IZMEĐU KORPORATIVNE DRUŠTVENE ODGOVORNOSTI I CENE KAPITALA PRIVREDNIH DRUŠTAVA KOJA SE KOTIRAJU NA NIGERIJSKOJ BERZI
}

\author{
Nyore Sandra Ofogbe ${ }^{*}$, Chidiebere Nnamani, Chika Anastesia Anisiuba i Charity Nkeiru \\ Ezuwore-Obodoekwe \\ University of Nigeria, Faculty of Business Administration, Accountancy Department, Nsukka, Nigeria
}

Cilj ove studije je analiza uticaja korporativne društvene odgovornosti na cenu kapitala privrednih društava koja se kotiraju na Nigerijskoj berzi. Godišnji panel podaci za 32 privredna društva, tokom perioda 2005-2019, koja se kotiraju na Nigerijskoj berzi, izabrani su po sopstvenoj diskreciji autora. Tomson Rojters Indeks je korišćen kao mera korporativne društvene odgovornosti, dok su cena sopstvenog, akcijskog kapitala i cena duga korišćeni kao mera cene kapitala. Saznanja do kojih se u studiji došlo pokazala su da postoji pozitivna-negativna beznačajna veza, kao i pozitivna-negativna značajna veza, između korporativne društvene odgovornosti i cene kapitala. Dobijeni rezultati potkrepljuju saznanja do kojih se došlo u naučnim radovima, posebno u razvijenim zemljama u kojima se ovaj aspekat naširoko istražuje. Zaključak je da privredna društva koja investiraju na korporativnu društvenu odgovornost imaju bolju šansu da po povoljnijoj ceni i nižem trošku dođu do kapitala. Bazirajući svoj stav na utvrđenim saznanjima, istraživači zagovaraju stav da je neophodno neprestano ulagati $u$ ona pitanja koja se tiču korporativne društvene odgovornosti, jer je taj način, ukoliko se to dosledno čini, može olakšati pristup novčanim sredstvima po povoljnijoj ceni.

Ključne reči: korporativna društvena odgovornost, cena kapitala, Tomson Rojters Indeks, cena sopstvenog akcijskog kapitala, cena duga

JEL Classification: M1, M4 